\title{
Foreign Policy Strategies towards Economic Development; Comparative Study of the Republic of Turkey and the Islamic Republic of Iran (2004-2013)
}

\author{
Vali Golmohammadi \\ Department of International Relations, Faculty of Human Science, Tarbiyat Modares University, Tehran, Iran \\ Email:V.golmohammadi19@gmail.com \\ Habib Atanejad \\ Department of Politics, Faculty of Human Science, Kharazmi University, Tehran, Iran
}

Ehsan Naghib Shahrebabaki

Department of Politics, Faculty of Human Science, Kharazmi University, Tehran, Iran

\section{Doi:10.5901/mjss.2015.v6n3s2p711}

\section{Abstract}

\begin{abstract}
Foreign policy is a complex of goals, orientations, and instruments that a state adopts vis-a-vis other states in order to achieve its national interests. The aim of foreign policy is to provide security, which covers a spectrum from territorial integrity to the development of economic facilities. After the collapse of the cold war bipolar system, the economic development has become the main agenda of developing countries' foreign policy. In the new era which is characterized by globalization, providing economic interests could be achieved through an active and development-oriented foreign policy. The emergence of the global political economy and the major changes in the principles of foreign policy directions, are reflecting the undeniable effects of state's foreign policy strategies over the economic power. This article, by using a comparative approach and qualitative method, investigates the influence of Turkey and Iran's foreign policy strategies on their economic development. To bourgeon Turkish economy and improve its position in the global economy, Turkey in the period of the current government (AKP) utilizes pragmatic, proactive, and development-oriented foreign policy strategies including westernization, regionalism, and peaceful coexistence which has led to an unprecedented economic growth. In contrast, the Islamic Republic of Iran, in the period of President Mahmoud Ahmadinejad (2005-2013), because of the emphasis on revolutionary ideas and aggressive strategies in foreign policy, has experienced irreversible economic stagnation.
\end{abstract}

Keywords: Foreign Policy Strategies, Economic Development, Turkey, Iran, AKP, Ahmadinejad

\section{Introduction}

The era which characterized by globalization is the age of sweeping changes. After collapse of the bipolar system structure, the emergence of global political economic system, important role of economic discussions, their effects on the politics in the world arena and fundamental changes in the international system structure, have made effectiveness of economic power over foreign policy unavoidable. Because of this situation, political economy of the world is also both a guide for the process of globalization and an effective element over the processes of national, internal, and global policies.

Accepting the new role and function of economic development, and the position of international institutions in directing global policies have necessitated the relations of the interaction from the side of governments because of utilizing capacities to achieve objectives and the best use of national resources. Therefore, presenting a clear and desirable perspective from the national economic system's output and the countries developmental plans, decreasing the risk of investment and increasing the security of the capital and the investor, giving priority to economics, trade and business, development of cooperation with global and local material institutions, and effective participation in the processes of negotiation and global interactions are among areas of economic diplomacies on the basis of which countries try to guarantee and stabilize their own local and global national interests security along with maximizing their own interests. Due to these substantial transformation, foreign policy makers should build their considerations on economic development for obtaining a remarkable position in global economy and international system. 
In such globalized environment, Turkey in the period of AKP has adopted its foreign orientations with economic aspiration that follows a pragmatic and proactive foreign policy with a view to consolidate the development in a beneficial direction. Turkey's economic prosperity during the last decade mainly has influenced by rational and developmentoriented foreign policy directions in which their principles have built on cost-benefit analysis. Turkey is considered as one of the developing countries with a strong desire and determination for industrialization, modernization and development during the AKP government.

Accordingly, Turkey's pragmatic, constructive, multi-dimensional, and development-oriented foreign policy is one of the paramount importance of unprecedented economic growth. The AKP foreign policy makers are aware of need to foster the connection between security, political stability, economic interest and foreign policy direction to gain sustainable economic development. The political and economic analysts of the world countries witnessed that as a consequence of the pragmatic and non-ideological foreign policies of the AKP government, in a six year period from 2002 to 2008, the GDP of Turkey increased from $\$ 300$ billion to $\$ 750$ billion and also the average annual per capita increased from $\$ 3300$ to more than $\$ 10000$. Consequently, for the first time since the foundation of the Republic of Turkey, its economy has reached the sixteenth position in world ranking and the sixth position in Europe.

In contrast, Iran's foreign policy in the period of Ahmadinejad's government (2005-2013) has failed to prosper economic conditions. Islamic Republic of Iran as one of the powerful countries with possessing the great resources of oil and gas, remarkable strategic position in the world and in its own area, and other potential factors, has not been able to foster its economic aspiration in the international economic domain. Passing of time and recession of power hardware made it lose the opportunities possible and increase the threshold of threat and the vulnerability of national economies. In the ruling of Ahmadinejad's government due to adopting aggressive, ideological and revolutionary foreign policy orientations, Iran has not met its national economic interests. Foreign policy of Iran during ninth and tenth government with skepticism on international trade organizations and criticism of the international system structure in one hand, and emphasize on revolutionary ideas and ideological consideration towards international development on the other, has caused extreme economic stagnation. Hence, while Turkey as a neighbor of Iran has experienced a high rate of economic growth, Iran's economy has stagnated and Ahmadinejad's aggressive foreign policy not only has failed to ameliorate Iran's economic condition, but also has led to unprecedented recession.

This article by using a comparative approach aims to investigate the impact of the Turkey and Iran's foreign policy strategies on economic development. In doing so, we utilize a theoretical framework to reach better understanding of both countries foreign policy directions toward economic issues.

\section{Theoretical Framework}

The theoretical framework of this paper rely on the basis of this assumption that in the era of globalization to achieve national economic objectives, creating a dynamic and synergistic interaction between the internal (national) and external (International) levels are essential. Foreign policy of each states provides such spaces for meeting economic aims through synergetic interactions. It is the focal point that in which development, foreign policy and globalization deeply and inextricably linked with each other. Consequently, if the above-mentioned interaction linked and development and welfare fulfilled, areas for prospering Freedom (Autonomy) ${ }^{1}$ and promoting self-esteem (Self-respect) as the fundamental goals of foreign policy will be provided (Mousavi Shafaee, 2011: 321).

In this regard, the development- oriented foreign policy facilitate and make such a synergetic cycle rotation possible in the process of globalization and through that, creates the dynamic interaction in motion and rotation cycle of globalization $\leftrightarrow$ development. The prerequisite for implementing of the following cycle; is becoming the extroverted development as a main paradigm of the citizens and politicians. However, in doing so requires a historic and decisive choice for getting rid of the security mentality and aggressive consideration in foreign policy and institutionalizing economy as a vital source of states legitimacy in the scope of international system.

\footnotetext{
1 Professor Rouhollah Ramezani argues that, Autonomy is refers to optimizing freedom of action in the international system; this means that countries policy makers apart from other country's influence and power are able to administrate and pursue their own specified foreign policy strategies. For more information, see: Ramezani, Rouhollah. 2001. An Analytical Framework for Examining the Foreign Policy of the Islamic Republic of Iran, translated by Alireza Tayyeb. Tehran: Ney Publications.
} 


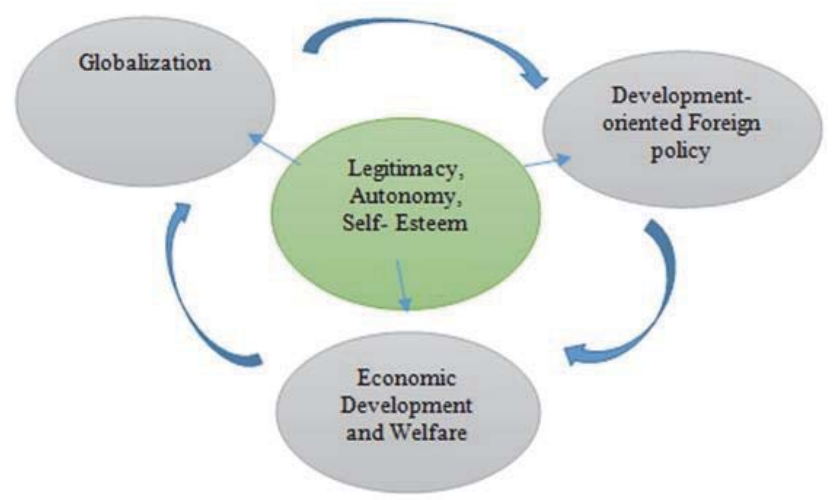

Figure 1: Interaction of Foreign Policy, Development and Globalization

Based on what form above, since the international status, prosperity, security and strength of any nation in the years ahead is subject to the entry and participation of the nation in the environment of globalization. At the same time, a necessary condition for playing an important role in this space depends on the amount and level of development of each country. So there is no escape except entry in the bilateral relationship; relationship in which, on the one hand, economic development is a necessary condition to entry into the global space with the aim of achieving prosperity, wealth, security and power for citizens and the government. On the other hand, the necessary condition for mowing forward development will be entering to the space of globalization and foreign policy properly provides such a synergetic contraction to link economic development and globalization.

In the era of globalization, according to the relations between foreign policy and economic development, comparing of the countries experiences through networking and globalization has provided (Seifzadeh, 2006: 24). This evident is placed in front of the eyes of people around the world that few countries of the developing world have been able to gain relative success in economic development and promote its international position. Undoubtedly, The countries that have achieved a high rate of economic growth, accompanied by mainstream of the global economy and the globalization process. Therefore, the countries who pursue the extroversive, proactive and development-oriented strategies in foreign policy are more successful than the ones who are following the introversive, offensive and isolated considerations.

\section{Economic Development Approaches; Iran and Turkey's Foreign Policy Considerations}

According to Manuel Castells, development- oriented governments rely their legitimacy on the creating and maintaining of economic development. In such complicated world system, Castells argued that all the states who planned to develop in economy should pursue a peaceful and pragmatic foreign policy approaches (Castells, 2001, 322). Similarly, in the point of Johnson views, the government who follows rational programs and economic orientation in foreign policy cannot pursues ideological and offensive guidelines simultaneously (movassagi, 2008, 158-159). In the internal policies, Development-oriented governments have continued to accumulate capital, strengthen their private sector entrepreneurs, middle class and the national bourgeoisie. Accordingly, in foreign policy strategies, by using various tools such as economic diplomacy, supporting manufacturer forces, advocating foreign investors and backing domestic companies investing abroad in regional and international levels have been implemented the economic development ambitious.

This section with a comparative study theme, provides an overview of the principles, criteria and key elements of the foreign policy of the Iran (the ninth and tenth government) and the Republic of Turkey (the AKP) to explain the Iran's ideological, security- driven, and aggressive foreign policy and in contrast, focused on the Turkey's pragmatic, proactive and development-oriented foreign policy orientations to achieve economic growth by using advantages of globalization opportunities, widespread interaction with other states and international organizations. Thus, the article firstly narrow down to the ninth and tenth governments of Iran's foreign policy and then scrutinize the successful experience of Turkey's AKP government leader's foreign policy strategies.

\section{Ahmadinejad's Confrontational Foreign Policy: Stagnation in Iran's Economy}

With the advent of the Islamic Revolution of Iran in 1979, Iranian foreign policy's priorities underwent a spectacular 
change. Iranian foreign policy has experienced many changes over the last thirty years ${ }^{2}$; during the decade of 1980's Iran's foreign policy was known for its radical and revolutionary content. In late 1980s and most of the 1990s, Iran has shifted its foreign policy from radical to a pragmatic one. In late 1990s, Iran started its moderate foreign policy stance that respects other states and different cultures. This major step to modernize the Iranian foreign policy was in complete contrast to its radical policy of the 1980s. However, this moderate approach could not continue for long and become radical again in 2005.

Since Mahmoud Ahmadinejad came in power, the Iran's foreign policy guidelines and directions entered in a new stage that characterized by Islamic ideology and revolutionary principles. If the former governments, especially the government's of Rafsanjani and Khatami emphesized on constructive interaction and reduction of tension with the West, the Ahmadinejad's governments defined themselves against the West and its allies in all parts of the world (Dehghani Firouzabadi, 2007: 67). Therefore, discussing about constructive dialogue with the world and reconcilliation with the international organizations was out of question. In contrast, the ninth and tenth govrnments of Ahmadinejad have essentialy based their foreign policy strategies towards third world countries such as the Latin America, the African poor countries that finally have not led to desired consequences.

Generally, Ahmadinejad's foreign policy was based on the following factors: 1) In justice- oriented government, nation-state is characterized in the framework of Islamic-Shia ideology and worldview; this government has completely based its discourse on religious; 2) Iran's national identity has an fundamental principle that is the priority of the Islamic revolution and ideals and values resulted from it; this identity is the product of "Islamic identity", "Islamic revolution" and "Iran" in which Islam and the Islamic revolution have priority over Iran; 3) In the realm of foreign policy, the Islamic revolution is not considered a national and limited revolution rather it is extra-national and extraterritorial, based on the belief that its ideology is religious and universal; 4) The main abjective of foreign policy is to expand the values pertinent to the sovereignty of Islam in order to establish an Islamic international community; accordingly, the existing international system structure is not desirable because it is not compatible with Islamic international community order; and, 5) The international system structure which determined by the Western superpowers has criticized by Ahmadinejad's foreign policy principles and in the same vein, the functions of international organizations like Security Council of United Nations and World Trade Organization have suspected by Iran's foreign policy makers (Eivazi, 2008: 209-219). Therefore, economic prosperity due to priority of ideological objectives has not recognized in main foreign policy strategies of the ninth and tenth governments of Iran.

During the ninth and tenth presidency, Iran's economy faced a significant transformation which has been Imposed severe economic pressure on Iran by international trade organizations and mostly the west countries. Alike former governments of Iran, Ahmadinejad's economy also has relied on national oil revenue. Despite increasing of oil revenue, Ahmadinejad's foreign policy considerations cause unexpected economic decadence of Iran in compare with neighbor countries like Qatar, UAE and Turkey. In terms of ninth and tenth governments of Iran, the negative consequences of their foreign policies include the following: Intensification of economic sanctions over Iran that have left different ominous effects on the economic condition and society psychiatric; reducing the level of foreign investment, especially in the energy sector; lack of access to advanced technologies because of confrontational and aggressive policies; weakening Iran's position in the international economic institutions; Inability to use existing capacity in the global economy because of the emphasis on ideological pattern in foreign orientations.

Comparing oil revenues of Ahmadinejad's governments with the period of Khatami and Rafsanjani obviously show that despite increase oil income in the two terms presidency of Ahmadinejad, Iran's economic condition did not experience a rapid growth in total economic output and Iranian per capita income. ${ }^{3}$ Following graph indicates that the rate of economic outputs as assessed by GDP rose about 19 percent in the two terms presidency of Ahmadinejad, which was lesser than the periods under reformist and constructivist governments of Iran (see Graph 1). Similarly, Ahmadinejad's economic ministry in compare with the periods under Khatami only experienced 10 percent of the increase in per capita income that was remarkably lesser than Khatami's presidency periods (Habibi, 2013: 7).

\footnotetext{
2 For further information about Iran's Foreign Policy analytical framework, see; Dehghani Firouzabadi, Seyed Jalal. 2005. A Discursive Change in the I.R.I's Foreign Policy, Haji Yousefi, Amir Mohammad. 2005. I.R.I's Foreign Policy in Light of Regional Developments, Mohammadi, Manouchehr \&Mottaghi, Ebrahim. 2005. "Constructive Interaction Doctrine in Iranian Foreign Policy, Molana, Mohammad \& Mohammadi, Manouchehr. 2009. Iranian Foreign policy in Ahmadinejad Government, Sajadpour, Mohammad Kazem. 2007. Conceptual and Research Frameworks for Examining the Foreign Policy of the Islamic Republic of Iran, Sariolghalam, Mahmoud. 2005. The I.R.I's Foreign Policy: Theoretical Revision and Coalition Paradigm.

3 To study further about the relations of Oil and foreign policy of Islamic Republic of Iran, see following source; Siros Feyzi, 2010, Interaction of oil and foreign policy in the Islamic Republic of Iran, a détente approach, International Journal of Foreign Relations, No.5, Spring 2010, pp. 109-137.
} 


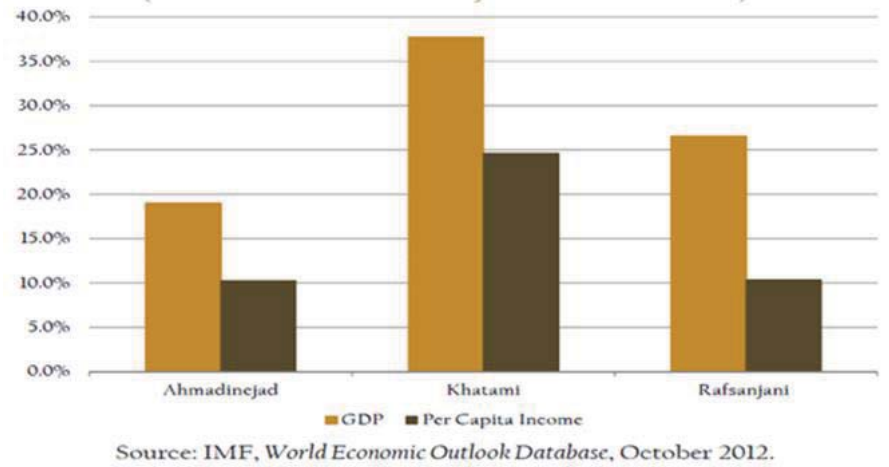

Graph 1: Increase in GDP and per capita income in the periods of Ahmadinejad, Khatami and Rafsanjani's presidency

Pursuing nuclear program by taking a confrontational policies during Mahmud Ahmadinejad's presidency, from 2005 to 2013, jeopardized economic interests and Iran became one of the most sanctioned states worldwide. Intense sanctions and the Ahmadinejad administration's misguided socioeconomic policies severely harmed the country. Crude oil exports decreased sharply, the inflation rate increased, domestic production fell, unemployment grew, the currency decayed, and the prices of consumer goods rose.(Azghandi, 2010, 218) Ironically, however, Ahmadinejad revolutionary foreign policy started to criticize international system order and apply a new confrontational policy toward western countries.

In the last years of the Ahmadinejad government, staunch efforts to pursue nuclear aspirations and implementing aggressive foreign policy towards international communities by mentioned government's foreign policy makers intensified the pressure on the Islamic Republic of Iran which subsequently provided spaces for Iran's economic rescissions. Assessing Iran's position in both regional and international level in the recent years and considering Middle East recent developments especially Arab Spring Which could improve the position of the Iran among the Arab nations, Not only did not show promising prospects in achieving ideological objectives, but also did not lead to benefitting of economic and political opportunities.

Iran's trade in 2011 was more than 207 billion dollars which included 131 billion dollars exports and 76 billion dollars imports that this volume of transactions in compare to the size of the Iran's economy is very frustrating. More than 80 percent of Iran's exports covered by the oil revenues that by intensifying sanctions over Iran's international trade transaction, this amount decreased to lower than 40 percent. Islamic Republic of Iran in terms of trade volume situated in 34 rank of the world trade that due to decreasing in the oil exports and restrictions on non-oil exports, this trend went too diminished. While, during of Ahmadinejad's presidency, Iran's foreign direct investment (FDI) share was less than one percent of world's FDI which included one billion and 400 million dollars, At the same time, Qatar attracted more than 32 billion dollars, Iraq gained 55 billion dollars and Turkey benefited more than 200 billion dollars foreign direct investment. Because of Ahmadinejad's aggressive foreign policy towards international organizations and international communities' skepticism about their capital security in Iran, in 2007 Iran loosed more than 15 billion dollars foreign investment. Iran's economic growth in 2011 recorded 2 percent while, in the last year of the tenth government it experienced negative trends that reached to $-0 / 9$ percent. In the years between 2008-2009, when the economy of the United States, Japan and Germany was in decline, economies of Brazil, China and Turkey grew respectively 9, 6/2, 6 percent (World Bank and IMF database, 2013). In contrast, due to prominence of ideals and revolutionary considerations in Ahmadinejad's presidency discourse, Iran's foreign policy makers have failed to prosper Iran's national economic growth and even have caused unprecedented economic stagnation.

Considering ideological and revolutionary goals rather than economic development ambitious by ninth and tenth governments' policy makers have focused their directions towards third world countries like Latin America, North Africa to grasp their supports in the international arena which its cost was more than expected worth. Contrary to the ninth and tenth governments' security-oriented and revolutionary approach which somehow highlighted Ahmadinejad's Third world consideration, there is a development-oriented view which cannot accept this policy in its current form. The proponents of this attitude believe that Iranian foreign policy is acting in a global sphere which by reliance on the triangle of politics, culture and economiy proposes an imperative on nations and policy makers that are exploiting assets (Arghavani pirsalami, 2013: 81-109). Hence, under these special circumstances which highly insisits on streghtening national power and accumulating of national wealth lie in centeral countries, the preference of Iranian foreign policy could not be relied 
just on peripheral countries such as the Latin America and the North Africa (Sariolghalam, 2005). Accordingly, Seifzade (2005), while stressing the Islamic Republic of Iran's particular geoghraghical position and the urgency of mobilizing internal and external copacity to accomplish the goals of foreign policy, argues that by cooperating with central development countries we can maximize material powers like the military and economic power and in collaboration with pheirpheral countries, we can back each other to cope with super powers ambitions and redistribute of power in the international system. (Seifzadeh, 2006: 9-22).

The period under review was specified by irreversible economic recession; declining national economic growth, increasing the rate of unemployment, causing unexpected corruption, raising inflation, and weakening Iran's position and credibility in the global economy domain. There is no doubt that most part of this economic stagnation is refers to aimless and non-harmonious foreign policy directions which have implemented by those who insistently believe in revolutionary and ideological objective rather than economic development- oriented considerations. Statistically, as shortly mentioned above, because of aggressive and ideological foreign policy of Ahmadinejad, Iran has failed to obtain the actual position of its economy in the Middle East and global economy.

\section{AKP's Proactive and Pragmatic Foreign Policy; Prosperity in Turkey's Economy}

After the rise of Islamists in Turkey (2002), Justice and Development Party (AKP) ${ }^{4}$ developed a democratic Islamist system which led to Turkey's unprecedented economic growth and became a successful regional model for the Islamic countries. The most important reason of this model attractiveness which began to formulate with the emergence of the Justice and Development Party, refers to its ability in integrating the Islamic values or Islamic traditions with the modern values. In fact, the AKP by combining democratic power with the support of emerging Islamic bourgeoisie in Turkey and relying on capital, media, and nationalist reformist discourse came to power and pursues their holistic development programs (Yavuz, 2009: 112-154). Indeed, the AKP elites by emphasizing on Turkey's historical heritage and its historical ties with the Muslim world and the West rather than the Islamic ideological heritage has improved Turkey's position in both regional and international realm.

The leaders of Justice and Development government by taking power in Turkey, have redefined Turkey's determined theoretical approaches in the international arena, in which this country is not trying to join the European Union as a marginal player, but reshapes its position as a bridge between the East and the West and as a most influential connector between the Middle East and the Europe. Because of considering these factors in foreign policy, Turkey unlike Iran has raised its economic growth rates and has become one of the most influential international player. By taking zeroproblem strategy in foreign policy ${ }^{5}$, Turkey has ameliorate its relations with the neighbor countries and subsequently has defined turkey as a sixth largest world economy. Undoubtedly, Turkish economic growth has occurred in the shadow of hegemonies, proactive, non-ideological and development- oriented foreign policy strategies of the AKP pragmatic elites.

The AKP government's performances in the domestic and international realm have picked up remarkable economic successes; Turkey's exports increased from 31 billion dollars in 2001 to 85 billion dollars in 2006. Unexpectedly, Turkey's exports during this period of time rose more than what considered in this country's long term strategic plans. This rapid growth led to improves turkey's rank of world's twenty-fifth in 2002 to twenty-second largest exporter in 2006. Turkey's exports growth continued more rapidly in the years of 2007 and 2008, which increased 25 and 23percent including 107 and 132 billion dollars respectively. However, with the outbreak of the financial crisis in Europe as Turkey's most important export market, Turkey's exports significantly dropped to 102 billion dollars in 2009. This decadence was result from of the EU's 64 percent share in Turkey's exports. By the occurring of this economic crises, the AKP policy makers focused their directions on the Middle East and the African markets to accelerate their economic developments. During implementing of this policy, Turkey's efforts achieved relative financial successes in which the African economies share in Turkey's exports increased to 12.3 percent in 2009 and this country was able to export about 10.2 billion dollars in such critical years (Turan, 2011: 55). The following chart noticeably shows the growth of Turkish exports in recent years;

\footnotetext{
${ }^{4}$ Adalat ve Kalkima Partisy

${ }^{5}$ For various study about Turkey's foreign policy strategies, see: Larrabee, F. Stephen and lan O. Lesser. 2003. Turkish Foreign Policy in an Age of Uncertainty. Santa Monica, CA: RAND; Murinson, Alexander. 2006."The Strategic Depth Doctrine of Turkish Foreign policy, "middle Eastern Studies, Vol. 42, No: 6, November; Onis, Ziya \& Suhnaz Yilmaz (2009), "Activism in Turkey during the AKP Era", Turkish Studies, Vol. 10, No. 1, March 2009; Aras, Bülent \& Polat, Rabia Karakaya. 2008. "From conflict to Cooperation: Desecuritization of Turkey's Relation with Syria and Iran; Cornell, Erik. 2001. Turkey in the 21Centuy, London: Routledge.
} 


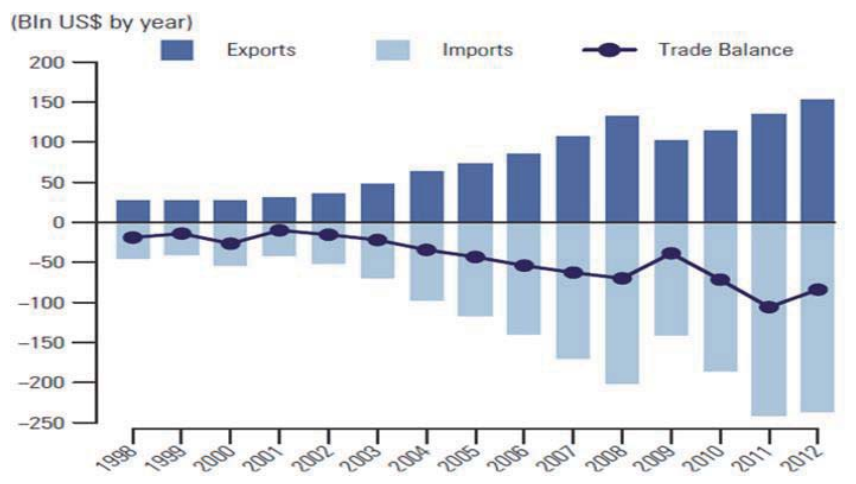

Chart 1: Total Export, Import and Trade Balance of Turkey

Sources: World Bank and Turkey's Ministry of economy, 2012

Before their rise in power, the AKP elites laid the theoretical basis for their foreign policy. Ahmet Davutoğlu, a prominent scholar and an architect of AKP's foreign policy wrote a book named The Strategic Depth ${ }^{6}$ in 2001 in which he deals with the significance of expansion of regional relations of Turkey as well as its economic interdependence role in stabilizing foreign policy. Specifically, he argues that the countries that are shifting from import substitution strategy to export promotion must follow their economic interests in the foreign policy domain. Based on this assumption, the Middle East should be one of the main targets of the Turkish government due to its important potentials including oil resources and booming markets. The growing interdependence requirements leaves no option for Turkey but to improve its regional relations (Ghanbarloo, 2012: 187-210).

In practice, trade and development concerns are among the important driving factors behind Erdoğan's government's rebuilding of its relations with the neighbors and regional states. Not only it is important to foster relations between Turkey and the regional states, but also Turks have been seeking establishment of peace and security between the third party countries, particularly between the regional states. That's why during the Erdoğan administration, Turkey strongly followed mediation for peaceful resolution of differences between regional countries. The assumption of the Turkish leaders has been that any political or economic crisis may impact Turkish economy and security. Therefore interests of Turkey necessitate active participation in resolving disputes and conflicts between regional countries (Kutlay, 2011: 77-82). Most prominent, though, is the liberal political economic explanation, according to which Turkey's "zero problem" policies reflect the dramatic expansion of trade linkages, rendering Turkey a new "trading state" (Kirsiçi 2009: 34).

One of the most important driver of change behind Turkey's new foreign policy is its emergence as a trading state. The concept of the "trading state" was first introduced by Richard Rosecrance ${ }^{7}$, but more recently, political scientist Kemal Kirisci applied this concept to Turkish foreign policy. Trading states emphasize the role of economic interdependence in their foreign policy, in contrast to states that rely on military capabilities and hard power. For trading states, national interest cannot be determined solely by narrowly construed national security concerns; economic considerations such as trade, the expansion of export markets, and foreign direct investment (FDI) are just as important(Ulgen,2010: 9-10). Several ongoing trends point to Turkey's new identity as a trading state, beginning with its economic development and integration with the global economy. The transformation of the Turkish economy and its new pragmatic orientation have led not just to the emergence of a new political constituency in favor of maintaining and increasing trade opportunities, but also to the widespread acceptance of a new foreign policy calculus that takes into account this economic reality. In fact, as Kirisci maintains, "this economic reality, the growth of foreign trade, has a direct effect on boosting economic growth, decreasing of unemployment, attracting foreign direct investments, rising tax revenues, and increasing of domestic supports towards the AKP foreign policy guidelines. (Kirisci, 2009: 29-57).

Regardless of Islamic and ideological background of AKP's decision makers, pragmatic foreign policy consideration particularly the expansion of cooperation with regional nations, accelerated the industrialization process

\footnotetext{
${ }^{6}$ Ahmet Davutoglu, "Stratejik derinlik, Türkiye'nin Uluslararasi Konumu [Strategic Depth: Turkey's International Position] (Istanbul: Küre yayinlari, 2001).

${ }^{7}$ Rosecrance, Richard, (1999), The Rise of Virtual State: Wealth and Power in the Coming Century, New York: Basic Book, The Rise of the Trading State: Commerce and Conquest in the Modern World (New York: Basic Books, 1986).
} 
and considerably reduced the economic vulnerability of Turkey. The main test for this assumption is the recent global economic crisis which began in 2007. Although Turkish economy faced various crises during the past decades, during the recent global economic crisis, thanks to close relations with non-Western powers and particularly neighbors and regional countries, Turkey managed to avoid the crisis despite severe reduction in European demands for their products. Due to such achievements Turkey is still trying to discover and exploit the outside world economic potentials including those in the regional markets. The public opinion of the regional countries witnessed that as a consequence of the policies of the AKP government, in a six year period from 2002 to 2008, the GDP of Turkey increased from $\$ 300$ billion to $\$ 750$ billion and also the average annual per capita increased from \$ 3300 to more than \$ 10000 (Ghanbarloo:2012: 206). Consequently, for the first time since the foundation of the Republic of Turkey, its economy has reached the sixteenth position in world ranking and the sixth position in Europe.

By adopting a development- oriented strategy during the rule of the AKP and after establishing stronger bonds between Turkey's economy and foreign policy, AKP's government tried to improve the international and regional position and credibility as well as the economic indices of Turkey. In practice the regional and international relations of Turkey became strongly active and in turn they brought about considerable economic and political achievements for Turkey. From a political perspective the international credibility of Turkey improved considerably. As an index, in October 2008, Turkey which was Europe's candidate for non-permanent membership in the UN Security Council, managed to join this UN organ as such through 151 votes of 192 member states of the UN. In 2011, while European countries were busy with devastating consequences of the global economic crisis, Turkey experienced a 7.5 percent economic growth. At the beginning of 2012, thanks to expansion of economic ties with regional neighbors, Turkey's economy was again ranked as the 16th economy of the world and the6th of Europe by $\$ 1$ trillion GDP (MacLeod, July 2, 2011).

\section{Conclusion}

In the new era which is highlighted by globalization, Foreign policy and economic development is inextricably linked with each other. Accordingly, those states who seek economic development should pursue a proactive and pragmatic foreign policy strategy that is mainly based on cost-benefit analysis. Thus, Due to the requirements of globalization and economic prosperity, policy makers should not follow an ideological and aggressive directions in foreign relations. In such an atmosphere, economic security makes one of the most important dimensions of national security. Provision of national security is not possible without economic power and development. That is why countries are involved in hard competition with others to gain economic benefits. They compete to attract direct foreign investments and negotiate with other countries to access the global markets. On the other side, they try to preserve their own local markets against irregular global influences, and simultaneously try to cooperate with other countries to form organizations to coordinate and normalize economic, commercial and financial relations in the form of economic agreements and in the framework of economic organizations. Beyond this, the roles played by nongovernmental economic activists and multinational companies have tremendously increased in the area of local and international economics and politics.

Turkey in the terms of AKP has been reaching a high rate of economic growth that has mainly affected by pragmatic and non-ideological foreign policy considerations. Turkey's economic growth is strongly influenced by its proactive and development-oriented foreign policy guild lines. From the very beginning of the foundation of the AKP, Turkish leaders have always looked at industrialization, modernization and development as strategic objectives. In contrast, Islamic Republic of Iran due to Ahmadinejad's confrontational, aggressive, and ideological foreign policy directions has failed to reach its economic aspirations. The period under Ahmadinejad experienced widely economic stagnation and due to aggressive foreign policy directions towards international organization, the West, some Arabic countries, and the structure of international system, Iran's credibility degraded and finally the foreign policy strategies of Iran securitized in the sight of public opinion of the world.

\section{References}

Azghandi, A, 2010, Islamic Republic of Iran's Foreign Policy Frameworks and Directions, First edition, Tehran, Ghomes Publication.

Azghandi, Alireza, 1997, Iran's Foreign Relations (A Puppet Government) 1941-1979. Tehran: Ghomes Publications.

Arghavani p. Fariborz, 2013, Third Wordism and Ahmadinejad's Foreign Policy, Iranian Review of Foreign Affairs, Vol. 4, No. 2, Summer 2013, pp. 81-109.

Castells, Manuel, 2000, The Rise of The Network Society: The Information Age: Economy, Society and Culture, Wiley Blackwell, Volume 1 , second edition, 15 august 2000.

Davutoğlu,Ahmet, 2008 "Turkey's New Foreign Policy Vision: An Assessment of 2007", Insight Turkey, Vol. 10, No. 1, (January- March 2008), p. 78. 
Dehghani Firouzabadi, Seyed Jalal, 2007. "The Discourse of Justice-Oriented Principlism in Ahmadinejad Government", Political Knowledge, spring and summer, Vol. 3, No. 1.

Eivazi, Mohammad Rahim, 2008, "An Analysis of Dr. Ahmadinejad's Foreign Policy". Rahbord Yas. No.14. summer.

Ghanbarloo, Abdohhah, 2012, The Role of the Economic Development Considerations in Turkey's Foreign Policy, Discourse: An Iranian Quarterly, Vol. 10, Nos. 3-4, Summer-Fall 2012: 187-210.

Habibi, Nader, 2013, The Economic Legacy of Mahmoud Ahmadinejad, Crown Center for Middle East Studies, June 2013, No.74: Available on the International Peace, Number 1, December 2010.

Kemal Kirişci, 2009, "The Transformation of Turkish Foreign Policy: The Rise of the Trading State," New Perspectives on Turkey, Special Issue on Turkish Foreign Policy, No. 40, 2009, pp. 38-39.

Kutlay, Mustafa, 2011, "Economy as the 'Practical Hand' of 'New Turkish Foreign Policy': A Political Economy Explanation," Insight Turkey, Vol. 13, No. 1, 2011, pp. 77-82.

MacLeod, Scott, 2011, "The Cairo Review Interview: Strategic Thinking," The Cairo Review of Global Affairs, July 2, 2011.

Mousavi shafaee, S.M. 2011, Development-Oriented Approaches toward Foreign policy of Iran; Necessities and Challenges, Journal of Politics, Tehran University Quarterly, No.2, Summer 2011, pp. 338-319.

Movassagi, S.A, 2008, Development and Development- Oriented Foreign Policy, published by National Conference of Developmentoriented Foreign policy, Strategic Research Center, Tehran, pp. 181-215.

Sariolghalam, Mahmoud. 2005. The I.R.I's Foreign Policy: Theoretical Revision and Coalition Paradigm. Tehran: Center for Strategic Research.

Sariolghalam, Mahmoud. 2011. Iran and Globalization: Challenges and Solutions. Tehran: Center for Strategic Research.

Seifzadeh, S.H, 2006, Foreign Policy of Iran, Tehran, Mizan Publication.

Seifzadeh, Seyed Hossein. 2005. Foreign Policy of Iran. Tehran: Mizan.

Seifzadeh, Seyed Hossein. 2006. Principles of International Relations, Tehran: Mizan.

Ulgen, Sinan, 2010, A Place in the Sun or Fifteen Minutes of Fame? Understanding Turkey's New Foreign Policy, Carnegie Endowment.

World Bank and Turkey's Ministry of Development, 2012, 'Sustaining High Growth: The Role of Domestic Saving', Turkey Country Economic Memorandum, Synthesis Report (Conference Edition), 14 March 2012.

Yavuz, M. Hakan, 2009, Secularism and Muslim Democracy in Turkey, Published in the United States of America by Cambridge University Press, New York. 